UDK 781:780.634:615.837

DOI: $10.4312 / \mathrm{mz} \cdot 52.2 .137-161$

\title{
Albinca Pesek
}

Samostojna raziskovalka / Independent researcher

\section{Tomaž Bratina}

Pedagoška fakulteta, Univerza v Mariboru

Faculty of Education, University of Maribor

\section{Gong and Its Therapeutic Meaning Gong in njegov terapevtski smisel}

Prejeto: 2. september 2016

Sprejeto: 7. oktober 2016

Ključne besede: zvočna terapija, zvočna kopel, kopel z gongi, stres, psihofizično ravnovesje

\section{IZVLEČEK}

Študija, ki je bila narejena s pomočjo vzorca 129-ih uporabnikov zvočnih kopeli z gongi v letu 2015 v Sloveniji, je pokazala, da vsi uporabniki dojemajo učinek zvočnih vibracij kot zdravilen in/ali sproščujoč. Izpričali so, da so dosegli notranji mir in boljše fizično in mentalno blagostanje, nov zagon za delo, željo po osebni rasti in druge pozitivne učinke.

\author{
Received: 2nd September 2016 \\ Accepted: 7th October 2016
}

Keywords: sound therapy, sound bath, gong bath, stress, psychophysical balance

\section{ABSTRACT}

The study, which was conducted utilising a sample of 129 users of sound baths with gongs in 2015 in Slovenia, has shown that all users define the effect of sound vibrations as healing and/or relaxing. They testified on achieving durable inner peace, on better physical and mental wellbeing, fresh impetus for work, desire for personal growth and other positive effects.

\section{Introduction}

Sound healing is one of the oldest ways of healing in history and its effects have been confirmed by modern science ${ }^{1}$ and praxis. ${ }^{2}$ It is a known fact that sound has been

1 Kimberly S. Moore, "A Systematic Review on the Neural Effects of Music on Emotion Regulation: Implications for Music Therapy Practice", Journal of Music Therapy 3 (2013): 198-242.

Maria L. Bringas, et al. "Effectiveness of Music Therapy as an Aid to Neural Restoration of Children with Severe Neurological Disorders", Frontiers in Neuroscience, 2015. This article is part of the research topic Music, Brain, and Rehabilitation: Emerging Therapeutic Applications and Potential Neural Mechanisms. Accessed on August 6, 2016, http://journal.frontiersin.org/ article/10.3389/fnins.2015.00427/full. Alfred A. Tomatis, The Conscious Ear (Barrytown: Station Hill Press, 1991).

2 Peter Hess, Singing Bowls for Health and Inner Harmony (Uenzen: Verlag Peter Hess, 2008). Lasanthi K.D. Manaranjanie, Music and Healing Rituals of Sri Lanka. Their Relevance for Community Music Therapy and Medical Ethnomusicology (Colombo: S. Godage \& Brothers (Pvt) Ltd, 2013).

Mojca Malek.Zvočna masaža. Accessed on June 15, 2016, http://muza.si/si/eho-udelezencev-narocnikov-reference/37-zvocna-masaza. 
used to facilitate altered states of consciousness. ${ }^{3}$ The desire to learn about our inner life energies and nature has led people to play the gongs in China, to use Himalayan singing bowls in Nepal, India and Tibet, and to play on various percussion instruments across the globe. Today, sound stimuli produced on rediscovered instruments are used together with modern technology ${ }^{4}$ for the sake of restoration of physical and mental balance. For a bit more than a decade, relaxing and healing with gongs has been practiced in Slovenia as well. Gong baths were introduced by individuals who, in most cases, received training from the world's best-known gong master Don Conreaux (b. in 1934) The training lasts for a few years and covers practical and theoretical contents from the fields of music, medicine, physics, philosophy, psychology and ethics. ${ }^{6}$ There is a growing number of individuals who use this type of relaxation to overcome everyday stress and related health problems and to establish physical and mental balance.

\section{Sound Therapy}

In this chapter, music therapy is the first concept that needs to be introduced. Music therapy is clinical use of music, based on evidence. It relates to the use of music for therapeutic treatment of physical, emotional, cognitive and social needs of individuals by trained professionals, who have completed the officially certified music therapy programmes? ${ }^{7}$ Based on the assessment provided by a professional music therapist, they decide about a suitable treatment, which can include listening to music and making music, i.e. singing, playing musical instruments and moving to music. Research in music therapy supports its effectiveness in numerous fields of rehabilitation therapies $^{8}$. Schools across the globe offer undergraduate and post-graduate studies for music therapists ${ }^{9}$ who find employment in different health and advisory centres. ${ }^{10}$

3 Otto-Heinrich Silber, et al, Klangtherapie (Battweiler: Traumzeit-Verlag, 2007), 142-143.

Csaba Szabó, "The Effects of Monotonous Drumming on Subjective Experiences", Music Therapy Today, 1(2004): 1-9.

4 David Gibson, The Complete Guide to Sound Healing (San Francisco: Sound Healing Center,

Sound \& Consciousness Globe Institute, 2013). Accessed on July 16, 2016, http://www.soundhealingcenter.com/instructors.html

5 Among the Slovenians, Mojca Malek is particularly active as pedagogue, organizer of events, and performer, who gives concerts together with Conreaux in different parts of the world.

6 International Gong Master Website. Accessed on August 11, 2016, http://www.toneoflife.com.pl/don/gong-master-trainingonline/gong-master-training-certification.

Sage Academy of Sound Energy. Accessed on August 5, 2016, http://www.sageacademyofsoundenergy.com/gong-camp-wdonconreaux-at-ananda-ashram-new-york.html.

7 American Music Therapy Association. Accessed on August 6, 2016, http://www.musictherapy.org/about/quotes/ Berklee College of Music. Acquired on 6. 8. 2016 from https://www.berklee.edu/music-therapy.

8 Gwendolin R. Watkins, "Proposed Physiological Mechanisms and Clinical Implications. Clinical Nurse Specialist," The International Journey for Advanced Nursing Practice 11 (1997): 43-50.

Herdis B. Sveinsdottir, Jon Snaedal, "Music therapy in moderate and severe dementia of Alzheimer's type: a case-control study," International Psychogeriatrics 18/4 (2006): 613-621.

Tony Wigram, et al, A Comprehensive Guide to Music Therapy: Theory, Clinical Practice, Research and Training (London: Jessica Kingsley Publishers, 2002).

9 E.g. Berklee College of Music (USA), University of Jyväskylä (Finland), University of Roehampton (United Kingdom), Universität für Musik und darstellende Kunst Wien (Austria).

10 E.g. Boston Children's Hospital and Nicklaus Children's Hospital in Miami (USA), Royal Children's Hospital in Melbourne (Australia), Krankenhaus für Psychiatrie, Psychotherapie und Psychosomatische Medizin Schloss Werneck (Germany), Volonterski centar Zagreb (Croatia), and Klinična bolnišnica za psihiatrijo v Ljubljani - Center za mentalno zdravje - oddelek Škofljica (Slovenia). 
Sound therapy is a type of therapy that uses sound to treat physical and mental conditions. The therapy is based on the premise that everything in life, including the human body, is a set of vibrations. If the vibrations become discordant and lose their rhythm, an individual's physical and mental state is hurt. ${ }^{11}$

Sound therapy is the conscious therapeutic application of sound frequencies for the purposes of healing, and with the intention of bringing the individual back into the state of harmony of the mind, body and spirit. This can be achieved by using different musical instruments or by generating frequencies on devices that have been constructed especially for this purpose. Studies have shown that sound therapies can affect brain waves, ${ }^{12}$ which causes relaxation and sets the frame for the healing processes. ${ }^{13}$

The history of sound healing goes back deeply to the history of the humankind. It is still an integral part of shamanic and other old healing practices in different parts of the world, where sound is an essential ritual component. ${ }^{14}$ Besides the use of instruments, such as e.g. drums, flutes, bells, or rattles, a special role is assumed by the human voice.15

Sound healing is based on the assumption that the human body is a set of vibrations that become discordant and lose their rhythm when an illness occurs. ${ }^{16}$ In order to understand sound healing better, we need to remind ourselves that atoms, cells and all living matter vibrate. The chosen sound waves enter the body and re-establish balanced waves in the body where these waves have been altered due to health conditions. The vibration or the sound in the audible or inaudible form (ultrasound, infrasound) represents energy. ${ }^{17}$ Sound has a creative force that shapes matter within us and outside of us. ${ }^{18}$

11 Encyclopedia of Alternative Medicine. Accessed on August 6, 2016, http://www.altmd.com/Articles/Sound-Therapy-Encyclopediaof-Alternative-Medicin.

12 Our brain works at different frequencies, which correspond to five levels of consciousness. Beta state (14-40 Hz) refers to the ordinary state when we think logically, are aware of the surroundings, and everything is under our strict control. Alpha state $(7,5-14 \mathrm{~Hz})$ denotes relaxed brain activity, occurring when we close our eyes, are about to sleep, or relax in daydreaming and meditation; this state awakes intuition and visualisation, and increases learning and memorizing capabilities. Theta state (4-7,5 $\mathrm{Hz}$ ) occurs in the sleep, in the REM phase. In this state of mind one can experience vivid visualizations and unique creativity. Delta state $(0,5-4 \mathrm{~Hz})$ is characteristic for deep sleep without dreams, which enables the body to regenerate and gets healed. Gama state (over $40 \mathrm{~Hz}$ ) is the fastest vibration in which we react very quickly, have insights into various situations and process information at a fast speed.

Deivanayagi S., et al, "Spectral Analysis Of EEG Signals During Hypnosis," International Journal of Systemics, Cybernetics and Informatics 4 (2007): 75-80. Accessed on May 30, 2016, https://apm.iitm.ac.in/biomedical/touchlab/papers/EEG.pdf.

Tina L. Huang, Christine Charyton, "Comprehensive Review of the Psychological Effects of Brainwave Entrainment," Alternative Therapies 14/5 (2008): 38-49.

"How Science Discovered The Silva Method." Accessed on August 2, 2016, http://www.silva.nl/wp-content/uploads/2014/12/ science-discovers-the-silva-method.pdf.

13 Helane Wahbeh, et al, "Binaural Beat Technology in Humans: a Pilot Study to Assess Psychological and Physiologic Effects," Journal of Alternative and Complementary Medicine 13/1 (2007): 25-32.

René-Pierre Le Scournec, et al, "Use of Binaural Beat Tapes for Treatment of Anxiety: A Pilot Study of Tape Preference and Outcomes," Alternative Therapies in Health and Medicine 7/1 (2001): 58-63.

Stuart Hameroff, et al, "Transcranial Ultrasound (TUS) Effects on Mental States: A Pilot Study," Brain Stimulation 6/3 (2013): 409-415.

14 See Kalinga Dona's article in this volume of Musicological Annual.

15 Gini Graham Scott, Shamanism (New York City: Alpha, 2002).

Ted Andrews, Sacred Sounds: Magic E Healing through Words \& Music (St. Paul: Llewellyn Publications, 1992), 15.

Wayne Perry, Sound Medicine. The Complete Guide to Healing with Sound and the Human Voice (Los Angeles: Musikarma Publishing, 2007).

16 Marjorie De Muynck, Sound Healing. Vibrational Healing with Ohm Tuning Forks (Santa Fe: Sound Universe, 2008), 1.

17 In Greek 'energia' means movement.

18 Stewart Pearce, Alkimija glasu (Brežice: Založba Primus, 2011), 19. 
Different frequencies affect our body differently. Some affect us pleasantly, while others may have the opposite effect. The difference between the daily sounds of the noisy environment and the chosen directed sounds lies in the fact that the former cause imbalances and the latter are expected to have a harmonious effect. If we are exposed to stress, noise and electromagnetic $\operatorname{smog}^{19}$ for longer periods of time, our body will react with pain and damages to the energy field, which leads to illness.

The most widely used methods that generate sounds in therapies are based on the so-called binaural tones. Already in 1839, Heinrich Wilhelm Dove (1803-1879) discovered that the brain transforms two tones that slightly differ in their frequences, when listened to simultaneously, into a third, fictitious tone. ${ }^{20}$ Gerald Oster (1918-1993), who continued Dove's research at the Mount Sinai Hospital in New York, described how the pulsation called binaural beat is caused. ${ }^{21}$ For instance, if a frequency of $350 \mathrm{~Hz}$ is fed to the left ear and $360 \mathrm{~Hz}$ to the right ear, the brain will perceive the $10 \mathrm{~Hz}$ difference and hear a tone that does not really exist. The brain will start resonating at a frequency of $10 \mathrm{~Hz}$, which is characteristic of the alpha range. Suzanne Evans Morris used an electroencephalogram ${ }^{22}$ and discovered that in this case the brain hemispheres start cooperating and brain waves in both hemispheres are equalised and vibrate at a frequency of $10 \mathrm{~Hz}$, as mentioned before. These early scientific discoveries were followed by numerous studies and the socalled Super-learning programmes. Here, learning takes place in the alpha state, memorisation is faster, communication efficiency enhanced and creativity awakened. ${ }^{23}$

Quite fast, binaural tones were started being used for relaxation, meditation and treatment of various pyhsical and mental disfunctions. There are different providers, ${ }^{24}$

19 "Nonionizing electromagnetic radiation propagated through the atmosphere by broadcast towers, radar installations, and microwave appliances, and the magnetic fields surrounding electric appliances and power lines, which is believed to have polluting effects on people and the environment; also called electromagnetic smog." Dictionary.com's 21st Century Lexicon. Accessed on August 7, 2016, http://www.dictionary.com/browse/electropollution .

Amparo Lázaro, et al, "Electromagnetic radiation of mobile telecommunication antennas affects the abundance and composition of wild pollinators," Journal of Insect Conservation 20/2 (2016): 315-324.

Jan Barcal, Frantisek Vozeh, "Effect of Whole-Body Exposure to HighFrequency Electromagnetic Field on the Brain Cortical and Hippocampal Activity in Mouse Experimental Model," NeuroQuantology 5/3 (2007): 292-302.

Sharon M. Abel, "The Extra-auditory Effects of Noise and Annoyance: An Overview of Research," Journal of Otolaryngology 1 (1990): 1-13.

Wayne Parry, Sound medicine. The Complete Guide to Healing With Sound and the Human Voice (Los Angeles: Musikarma Publishing, 2007), 198-99.

Martin Blank, Reba Goodman, "Electromagnetic fields stress living cells," Pathophysiology: the official Journal of the International Society for Pathophysiology 16/2-3 (2009): 71-78.

Heba M. Fahmy, et al, Effect of Radiofrequency Waves Emitted From Conventiona WIFI Devices on Some Oxidative Stress Parameters in Rat Kidney," Drug Metabolism E Toxicology, 6/5 (2015): 1-6. Accessed on April 1, 2016, http://www.omicsonline. org/open-access/effect-of-radiofrequency-waves-emitted-from-conventional-wifi-devices-on-some-oxidative-stress-parametersin-rat-kidney-2157-7609-1000195.pdf

20 JSTOR - digital library of academic journals, books, and primary sources. Heinrich Wilhelm Dove, Proceedings of the American Academy of Arts and Sciences, 15, 383-391. Accessed on August 5, 2016, https://www.jstor.org/stable/25138588?seq=9\#page_ scan_tab_contents.

21 Gerald Oster, "Auditory Beats in the Brain," Scientific American (1973): 94-102. Accessed on February 2, 2015, http://www. amadeux.net/sublimen/documenti/G.OsterAuditoryBeatsintheBrain.pdf.

22 Suzanne Evans Morris, The Facilitation of Learning (Self-publishing, 1973), 15.

23 Colin Rose, Malcolm J. Nicholl, Accelerated Learning for the 21th Century (New York: Dell Publishing, 1998). Sheila Ostrander, et al, Super-Learning 2000 (New York: Dell Publishing, 1997).

Variations of Superlearning programmes can be found e.g. at Holistični center Karnion (Slovenia).

24 Holosync Audio technology: https://www.centerpointe.com/v2/

The Morry Method: http://www.themorrymethod.com/tmm.php?id=6

Zenlama: http://www.zenlama.com/ 
that offer help to individuals and groups and sell different products, i.e. CDs for relaxation in alpha state. The chosen frequencies affect individual centres in the brain so as to facilitate creativity, communication, concentration, etc. These products also contain neuro-linguistic programmes, guided meditations, programmes for sleep quality, etc.

\section{The Use of Gong in Various Times and Places}

Gongs supposedly date back to the Bronze Age, i.e. the period approximately from 3000 BC to 2000 BC. There are several possible interpretations as to their origin. While some believe that the gong had originally been used as a bronze shield that was struck to give sign of attack or retreat, other sources say that it was a bronze disc that represented the sun and was supposedly worshipped by early agricultural peoples. ${ }^{25}$

Eminent English percussionist James Blades (1901-1999) wrote in his book on percussions that the earliest written mention of the gong was in $6^{\text {th }}$ century China, during the reign of Emperor Hsuan Wu (500-516). ${ }^{26}$ Some ethnomusicologists attribute the origin of the gong to ancient Greece, from where it supposedly spread all the way to India with Alexander the Great in the $4^{\text {th }}$ century BC. The original gong was thus supposedly a Greek instrument called echeion. ${ }^{27}$ They were used in theatre plays and in death rituals.

In Javanese mythology, the gong was created by the divine king Sang Hyang Guru in 330. He needed the gong to summon the gods. He joined two gongs thus giving an impetus to the later formation of a gamelan. ${ }^{28}$

In Eastern civilizations, gongs were used on various occasions, to signal, to accompany dances and the action in theatres, to mark different events, such as births, deaths or weddings, as exorcism tools, in meditations and to facilitate altered states of consciousness. In some cultures, gongs were considered a status symbol and an indicator of wealth and high social rank. ${ }^{29}$

In the $6^{\text {th }}$ century BC Gautama Buddha recognised the sound of the gong as an exceptionally powerful tool in meditation and transformation of consciousness. He sent 26 monks to the lands surrounding Nepal and tasked them to write "Tan Loi" on every gong that they found, which means Happiness has arrived, God has returned to Earth. ${ }^{30}$

Gongs continue to play an important role in the spiritual life in Southeast and East Asia. In Indonesia, the gong is one of the most important musical instruments in the gamelan ensemble, which is characteristic for the islands of Bali and Java. The gongs

Brain.fm: https://www.brain.fm/app

Roger K. Cady, Norman Shealy, Neurochemical Responses to Cranial Electrical Stimulation and Photo-Stimulation via Brain Wave Synchronization (Springfield: Shealy Institute of Comprehensive Health Care, 1990), 11.

25 Mehtab Benton, Gong joga. Zdravljenje in razsvetljevanje s pomočjo zvoka (Ljubljana: Center Sospita Rea Silvia Novak Co. K. D., 2010), 8.

26 James Blades, Percussion Instruments and Their History (Westport, Connecticut: The Bold Strummer, Ltd., 1992), 93.

27 Mehtab Benton, Gong joga. Zdravljenje in razsvetljevanje s pomočjo zvoka (Ljubljana: Center Sospita Rea Silvia Novak Co. K. D., 2010), 8.

28 Philip McNamara, Gongs and Tam-Tams - A Guide for Percussionist, Drummers and Sound Healers (Layerthorpe: York Publishing Services Ltd., 2012), 10.

29 Ibid., 11.

30 Sheila Whittaker, Sound Healing With Gongs (York: Healing Sound, 2010), 25. 
are tuned differently and have a characteristic form with a raised centre. In China, a pair of gongs is an essential part of the orchestra for Chinese opera. The larger gong is usually used to announce the entrance of major players, especially men, and to identify points of drama. The smaller gong is used to announce the entrance of women and to identify points of humour. In Japan, gongs were part of Shinto ${ }^{31}$ ceremonies for centuries as well as of secular ceremonies, such as festivals, theatre and dances. Today, they are used to start the beginning of sumo wrestling contests and in the traditional Japanese kabuki theatre. ${ }^{32}$

The gong was first used in western music in the Funeral Music for Mirabeau (1791) by French composer François-Joseph Gossec (1734-1829) that was composed in honour of Honoré Mirabeau (1749-1791), who played an important role in the French Revolution. The gong can be found in Luigi Cherubin's (1769-1842) Requiem from 1816, in Gioachino Rossini's opera Armida from 1831 and in Vincenzo Bellini's (1801-1835) opera Norma. A specially efficient combination of cymbals and untuned tam-tams was used by Hector Berlioz (1803-1869) is his Requiem in 1837. In the next few decades, the gong became an important part of the percussion ensemble, as it can be found in the works of important composers such as Richard Wagner (1813-1883), Gustav Mahler (1860-1911), Sergei Rachmaninoff (1873-1943), Igor Stravinsky (1882-1971), Sergei Prokofiev (1891-1953), Dmitri Shostakovich (1906-1975), Oliver Messiaen (1908-1992), Pierre Boulez (1925) and others. ${ }^{33}$ Karlheinz Stockhausen (1928-2007) specifically ordered the gong for his Mikrophonie I (1964) from the renowned Swiss percussion manufacturer Paiste. ${ }^{34}$ In Mikrophonie I, two percussionists play a gong, another pair of players uses microphones to "catch" the sounds and the last two performers are seated in the audience and apply resonant bandpass filters to the microphone outputs to distribute the sound. ${ }^{35}$

The gong has also played a role in psychedelic rock music (Pink Floyd) and was also used by ensembles such as Led Zeppelin and Queen. In jazz music, it is associated with Miles Davis (1926-1991) and Charles Mingus (1922-1979). ${ }^{36}$

\section{Types of Gongs}

What is a gong and what is a tam-tam? Gongs usually have a raised centre and tamtams have a flat front surface. However, this is not always the case, as the renowned

31 The collocation Shin-to means god or the way to god. Shintoism is an old Japanese religion, animistic and polyteistic.

32 Mehtab Benton, Gong joga. Zdravljenje in razsvetljevanje s pomočjo zvoka (Ljubljana: Center Sospita Rea Silvia Novak Co. K. D., 2010), 10.

James Blades, Percussion Instruments And Their History (Wespot: The Bold Strummer, Ltd., 2005), 93-94.

33 Philip McNamara, Gongs and Tam-Tams - A Guide for Percussionist, Drummers and Sound Healers (Layerthorpe: York Publishing Services Ltd., 2012), 11-12.

34 Sheila Whittaker, Sound Healing With Gongs (York: Healing Sound, 2010), 27.

35 Christopher Burns, "Realizing Lucier and Stockhausen: Case Studies in the Performance Practice of Electroacoustic Music," Journal of New Music Research 1 (2002): 59-68. Accessed on December 12, 2015, http://sfsound .org/ cburns/writings/burnsicmc2001.pdf

36 Isabelle Frohne, "Gongspiel und Gegenwart," in Heilende Klänge. Der Gong in Therapie, Meditation und Sound Healing (Uenzen: Verlag Peter Hess, 2007), 9-22

Glenn Povey, Echoes: The Complete History of Pink Floyd (Bovingdon: Mind Head Publishing, 2007). 
gong manufacturer Paiste creates so-called planet gongs, which are flat and tuned to "planet frequencies". ${ }^{37}$ Numerous references suggest that flat gongs of indefinite pitch are called tam-tams. ${ }^{38}$

Until 1950, English composers did not specifically define whether a gong or a tamtam should be used, as can be seen in the sheet music by Gustav Holst (1874-1934), Benjamin Britten (1913-1976), Havergal Brian (1876-1972) and others. In his Symphony No. 8 from the period 1953-1955, Ralph Vaughan Williams (1872-1958) defines specifically tuned gongs. ${ }^{39}$

Regarding their position, we differ suspended gongs, bossed or button gongs and hand gongs. The most frequent are the first ones, since they are found in different cultures and are used for production of different soundscapes. The bossed gongs are placed on the resonant body, as it is the case at gamelan ensembles. ${ }^{40}$ The hand gongs are held in hands and are most often found in China. Mostly, they occur in dramas, folk performances and festivals ${ }^{41}$. In sound therapies, suspended gongs and hand gongs are used.

Gongs are made mostly from 70 to 80 per cent of copper and 20 to 30 per cent of tin. Some other metals can be added too, such as zinc, nickel, lead and iron. Gongs of a higher quality contain more copper, and those of a lower quality contain more tin. ${ }^{42}$

\section{The Gong and Sound Baths}

Despite many studies and explanations carried out in the last five decades focusing on the effect of the gong sound on our whole being a lot of its characteristics remain scientifically unexplained. The studies by Johannes Heimrath, Anne Kathrin Nickel, David Akomb, Peter Hess and others point to the efficiency of sound therapies in treating physical, mental, emotional and spiritual disorders. ${ }^{43}$

The sound of a gong is strong and rich in harmonics. By means of sound waves, dermatomes ${ }^{44}$ are stimulated and transfer the message of vibration into the body. The

37 In 1978, Swiss mathematician and musicologist Hans Cousto published the results of his research on cosmic octaves, based on astronomic data, in the book The Cosmic Octave: Origin of Harmony (Simon \& Leutner Publishing). According to this source, the frequencies of the planets are as follows: Mercury - tone D (141.27 Hz), Venus - A (221.23 Hz), Moon - G sharp $(210.42$ Hz), Earth - C sharp (136.10 Hz), Mars - D (144.72 Hz), Jupiter - F sharp (183.58 Hz), Saturn - D (147.85 Hz), Uranus - G sharp (207.36 Hz), Neptun - G sharp (211.44 Hz), Pluto - C sharp (140,25 Hz), Sedna - C (128.10 Hz), Nibiru - E (161.26 Hz), Kyron - D sharp $(151.27 \mathrm{~Hz})$. Sounds in space are recorded by NASA Agency. Although there seems to be a vacuum in space, it does not mean there are no sounds in it. They exist as electromagnetic vibrations recorded by the Agency by means of specially designed devices, such as NASA Voyager, INJUN 1, ISEE 1 and HAWKEYE.

38 Philip McNamara, Gongs and Tam-Tams - A Guide for Percussionist, Drummers and Sound Healers (Layerthorpe: York Publishing Services Ltd., 2012), 5.

39 Ibid., 5.

40 The Javanese gong sets in two horizontal lines of 10 or 14 units are called bonang. The higher tuned gong set is called bonang panerus, the lower tuned bonang barung, and the lowest tuned bonang panembung.

41 A gongs of this type is called Xiao gong, which means 'a small gong'.

42 Philip McNamara, Gongs and Tam-Tams - A Guide for Percussionist, Drummers and Sound Healers (Layerthorpe: York Publishing Services Ltd., 2012), 12.

43 Mehtab Benton, Gong joga. Zdravljenje in razsvetljevanje s pomočjo zvoka (Ljubljana: Center Sospita Rea Silvia Novak Co. K. D., 2010), 34-37.

44 A dermatome is an area of skin that is mainly supplied by a single spinal nerve. Sound stimuli travel along sensory neurons into different parts of the body and affect the vibrations of different organs. 
most positive results of treatment are observed in eliminating headaches, migraines, menstrual conditions, spinal pains and injuries. The sound balances the activity of various glands and eliminates breathing problems.

Exposure to the gong sound enables psychoacoustic passage into different states of consciousness and into the field of unconsciousness. Statistically significant positive changes have been notices in treating autists, ${ }^{45}$ schizophrenics ${ }^{46}$ and drug addicts. ${ }^{47}$ In a meditative state, achieved by playing the gongs, pressures and the contents of the mind become loose. Easiness leads to unusual and so called superior states of mind, which are otherwise experienced by drug addicts. Yogi Bhajan developed the Superhealth programme in which the gong is used for treating addicts or restoring a healthy electromagnetic field since sound balances the activity of the nervous system and opens spiritual connections. ${ }^{48}$

In gong baths or sound baths, as relaxations with sound are called nowadays, exclusively gongs or gongs together with other musical instruments or sound-producing devices are used, such as Himalayan singing bowl, didgeridoo, shamanic drum, shruti box, ${ }^{49}$ rattles, shells, pipes, xylophones, metalophones, cordophones, and litophones.

Gong baths can be preformed for individuals or groups. It is recommended that users are covered with blankets, comfortably lying on soft sleeping pads. Sound sessions usually last for about 45 minutes and consist of several consecutive parts, planned by the performer in advance, but are generally a result of improvisation. The underlying theme is the gong playing interjected by the sounds of other instruments. Prior to the start, the users receive preparation to the sound session through conversation, relaxing exercise and conscious breathing. They learn about the potential mental, emotional or physical reactions that can occur during the session. The therapist also explains to them that these manifestations are normal and that users should feel completely safe.

A usual sound bath begins with dynamically less prominent segments, then rises into the climax, which is, as a rule, performed by gongs, and slowly calms down and finally fades away in quiet sounds. After the sound session, its users remain silent for about two minutes and then, if they wish, they share their experiences with therapist and other participants, if any. Most frequently, individuals' experiences are related to seeing different colours (synesthetic manifestations), slight pains, that can be sensed in the body parts where fractures or surgeries had occurred, creeps in some body parts, and a sense of heavy legs and arms. Generally, the users of sound baths feel relaxed and recovered. ${ }^{50}$

45 Kim \inah, "Emotional, Motivational and Interpersonal Responsiveness of Children with Autism in Improvisational Music Therapy," Autism 13/4 (2009): 389-409.

46 Nakul Talwar, et al, "Music Therapy for In-patients with Schizophrenia," The British Journal of Psychiatry 189/5 (2006): $405-409$.

47 Genevieve Dingle, et al, "Can Music Therapy Engage Patients in Group Cognitive Behaviour Therapy for Substance Abuse Treatment?" Drug and Alcohol Review 27 (2008): 190-196.

48 Mehtab Benton, Gong joga. Zdravljenje in razsvetljevanje s pomočjo zvoka (Ljubljana: Center Sospita Rea Silvia Novak Co. K. D., 2010), 37.

49 It is a type of harmony meant for drone accompaniment of singers or instrumentalists.

50 Peter Hess, Singing Bowls for Health and Inner Harmony (Uenzen: Verlag Peter Hess, 2008).

Lasanthi K.D. Manaranjanie, Music and Healing Rituals of Sri Lanka. Their Relevance for Community Music Therapy and Medical Ethnomusicology (Colombo: S. Godage \& Brothers (Pvt) Ltd., 2013).

Mojca Malek, Zvočna masaža, accessed on June 15, 2016, http://muza.si/si/eho-udelezencev-narocnikov-reference/37-zvocnamasaza. 
Since body cells exposed to sound vibrate strongly and remove toxins it is necessary to drink large quantities of water so that the body can cleanse.

\section{Don Conreaux}

Gong baths are currently performed in various parts of the world primarily due to the engagement of the gong master Don Ayerdon Conreaux, who provided training for thousands of learners, including the co-author of this article. He started playing the gong in 1969 when he was still an actor, director, writer and scriptwriter in Hollywood. As a theatre person, Conreaux was interested in psychological profiles of people and different ways of life. At some point, he decided to dedicate himself to search for techniques to improve the quality of human life. His yoga teacher handed over to him some of his experiences of playing the gong. Guided by his intuition, Conreaux soon developed new techniques and understandings. "You never forget the sound of gong once you hear it", he claims. ${ }^{51}$

Contreaux found major encouragement for his investigation of the gongs in the books of Dane Rudhyar (1895-1985), American composer, pianist, writer and astrologist. He was particularly impressed by Rudhyar's views about the gong as a symbol and instrument of holistic resonance. ${ }^{52}$

Don Conreaux is also known under the names Baba Don and Guru Jagat. He is one of the five students of Kundalini Yoga ${ }^{53}$ iniciated by Yogy Bhajana. However, his first teacher, when he was still a teenager, was Paramahansa Yoganananda, an Indian yogi and guru who first introduced meditation and Kriya Yoga ${ }^{54}$ to millions of people in the West.

Based on his experiences in Kundalini and Kriya Yoga as well as intensive gong playing, Contreaux developed Gong Kriya Kundalini Yoga, which includes thirty-nine exercises for muscles, accompanied by breathing technique called breath of fire. His teaching suggests that these exercises help opening meridians, ${ }^{55}$ which enable energy to regain its smooth flow over the body and restore physical and mental balance as a precondition for health, peace of mind and access to a higher level of consciousness.

Contreaux initiated international movement for global peace named World Peace Bell Gardens. As an expert in acoustics, Contreaux together with Robert Gulik designed geometrical organisation of gongs and wind chimes representing resonating

Karin Brandt, "Klangmassage-Therapie mit alters- und demenzkranken Menschen, Klang-Massage-Therapy 8 (2011): 10-11.

Sybille von Fragstein, "Klangmassage-Therapie in der ambulanten Arbeit mit behinderten Menschen. Klangmassage-Therapie mit alters- und demenzkranken Menschen," Klang-Massage-Therapy 8 (2011): 12-14.

Andreas Hüne, "Klangmassage bei Menschen mit psyhischer Behinderung," Klang-Massage-Therapy 8 (2011): 40-41.

51 Dane Rudhyar's most important books related to music are: Claude Debussy And His Work (1913), Disonant Harmony (1928),

The Rebirth of Hindu Music (1928), The New Meaning of Sound (1930), Art as a Release of Strength: Seven Essays on the Philosophy of Art (1930) and The Magic of Sound and the Art of Music (1982).

52 Don Conreaux, Magnum Opus of the Gong (New York: Mysterious Tremendum, 1994), 5.

53 Kundalini is the name for sleeping energy in human organism. It is supposed to be located in the lower part of the spine, in a snake shape. It is believed that one can wake it up by means of yoga and live mystical experiences.

54 Kriya yoga consists of techniques and exercises which stimulate spiritual development.

55 Meridians are paths through which, according to acupuncture theory, lifeal energy flows over the body. Meriam-Webster Dictionary. Accessed on August 7, 2016, http://www.merriam-webster.com/dictionary/meridian. 
flame of peace. In his own words, "The sound of the gong helps people to let go their resentments, limitations, and prejudices; it brings peace, friendship and love. The first day of world peace will come when people of the Earth will take each others' hands, give thanks to life and listen to the song of gongs, announcing peace on the planet." 56

Conreaux is also linked to the Mysterius tremendum ensemble. The name of the ensemble comes from the "mystical chord" 57 of the composer Alexander Nikolayevich Scriabin who believed that this harmony binds humankind and the kingdom of nature. ${ }^{58}$ This framework brings musicians together to improvise without preliminary rehearsals by using gongs, Himalayan singing bowls, didgeridoo, bells, shells, drums, and multipart singing accompanied by shruti box. ${ }^{59}$

Don Conreaux runs educational programmes for sound therapists interested in gongs and complements them with performances. His practical work is supported by the ideas that he had presented in his books: Gongs of Our Solar System, Magnum Opus of the Gong 1 \& 2, Music of Wholeness, Gong Essays, Sacred Geometry of Starhenge, ${ }^{60}$ The Universal Chiometer, ${ }^{61}$ The Kriya Kundalingi Gong Yoga, Syntonic Science by Dan Rudhyar Today, Global Movement for the Gong and The Philosophy of the Gong. ${ }^{62}$

In 2014, he celebrated his eightieth birthday at the Pohorje mountain chain in Slovenia, the place he loves and keeps visiting for over a decade as a teacher. As has been presented in this chapter of the article, the sound aspects of his work are closely related with environmental consciousness, peace activism, healing and spiritual growth.

\section{Empirical Part}

\section{Research Problem}

The increasing interest in relaxing and healing by means of sound in Slovenia and abroad has encouraged us to explore the effects of sound baths and sound harmonisations on individuals. We were interested whether relaxing and healing qualities can be attributed to the sound of musical instruments such as gongs, Himalayan singing bowls, shamanic drums, chimes, shells, and rattles.

56 Mojca Malek, "An interview with the senior of Kundalini Krjya and Gong Yoga, Don Conreaux: Zvok gonga ruši zidove med ljudmi. (The sound of the gong destroying walls among people)," Sončeve pozitivke. Accessed on February 4, 2015, http:// www.pozitivke.net/article.php?story=Zvok_Planetarni_Gongi_Don_Conreaux\&query=gongov.

57 Malek, "An interview with the senior of Kundalini Krjya and Gong Yoga, Don Conreaux: Zvok gonga ruši zidove med ljudmi. (The sound of the gong destroying walls among people)."

58 Scriabin's study of theosophical scripts made his music a reflection of his new mysticism. His intention was to link his audience to angels and spirits of nature and bring them into the state of ecstasy. In his life, he wished to follow the message of the great mystery in the way that he would bring the audience to dematerialisation of their ego by means of gong-like sounds. (Conreaux, Magnum Opus of the Gong. Selected Essays, 5.)

59 An Indian sound device intended to provide drone accompaniment to singing or playing of a melodic instrument.

60 Starhenge is a set of natural stone blocks or pillars in the form of concentric rings. It was designed by Conreaux to offer individuals an opportunity to walk in them and meditate.

61 Chiometer is a synthesis of different esoteric systems and principles of healing, such as the meridians of the Chinese medicine, chakras, the tree of life form, kabala, astrology, colours, tonalities, etc. Systems that enable an individual a broader insight into the reality of being are connected in eleven concentric rings.

62 In most publications the years of publication are not specified. 


\section{The Purpose of the Research}

In the research, we studied the following aspects of sound baths:

- how often do the users attend sound baths

- for how long have the users known sound baths with gongs and other musical instruments

- what kind of feelings do the users experience at sound baths with gongs

- which physical and mental states are affected by the sound baths in the most positive way

- which intensities of sound baths do the users like most

- how do the users define sound baths - as relaxing, healing or both

For some established facts potential differences regarding age group, education background and time span of experience in therapies were checked.

\section{Description of the Sample}

The sample is described considering independent variables as they were used in the processing. The sample includes 129 units/users of sound therapies with the gongs in 2015. The structure of the sample includes users aged above 20, of different social strata and educational background. The sample can be defined as a random sample of known population. The population is represented by users of sound baths carried on in separate therapeutic groups led by different performers within Slovenia.

\begin{tabular}{|l|c|c|}
\hline Age & $\mathrm{F}$ & $\mathrm{f} \%$ \\
\hline under 30 years & 16 & 12.4 \\
\hline 30-40 years & 37 & 28.7 \\
\hline 40-50 years & 46 & 35.7 \\
\hline over 50 years & 30 & 23.3 \\
\hline Total & 129 & 100.0 \\
\hline
\end{tabular}

Table 1: Structure of users according to age groups.

The sound bath users were divided into age groups. The major part is represented by users aged between 40 and 50, being followed by users between 30 and 40. The smallest share of sound bath users are those younger than 30. The prevalence of individuals aged between 30 and 50 can be attributed to the fact that one of the crucial factors for the decision to join relaxing activities is intense activity and the related stress in this life period. Another factor can be that this group is more widely informed on alternative ways of relaxation and healing. 


\begin{tabular}{|l|c|c|}
\hline Education & $\mathrm{F}$ & $\mathrm{f} \%$ \\
\hline secondary school & 34 & 26.4 \\
\hline higher education, university & 82 & 63.6 \\
\hline master's degree, doctorate & 13 & 10.1 \\
\hline Total & 129 & 100.0 \\
\hline
\end{tabular}

Table 2: Structure of users according to education background.

About $63.6 \%$ of users of sound baths with the gongs have accomplished higher education or university; they are followed by users with secondary education. The fewest users $(10.1 \%)$ are with academic titles. The fact that sound baths are mostly attended by individuals with formally higher education can be attributed to the fact that these individuals are more keen on reading and staying in touch with options to achieve better life quality, where, among other things, also care for psychophysical balance belongs.

\begin{tabular}{|l|c|c|}
\hline Frequency of using sound baths & F & f \% \\
\hline once a week & 6 & 4.7 \\
\hline twice a month & 7 & 5.4 \\
\hline once a month & 21 & 16.3 \\
\hline occasionally (less than once a month) & 95 & 73.6 \\
\hline Total & 129 & 100.0 \\
\hline
\end{tabular}

Table 3: Structure according to frequency of using sound baths.

Most users attend sound baths with gongs occasionally, $16.3 \%$ uses them once a month. The share of those who use sound baths more than monthly or more often is relatively small - a bit over $10 \%$.

\section{Collecting and processing of data}

To collect data, a survey questionnaire was prepared, consisting of 10 questions, divided into groups. The first group included questions on the time span of being informed about sound baths with gongs and the frequency of using them; in the second one, there were questions on the desired intensity of sound baths, personal feelings and experiences at sound baths. In the third group of questions, the users expressed their personal attitudes towards sound baths and assessed the probability that they would recommend sound baths to others too. The fourth group of questions was meant to check the effects of sound baths to various psychophysical states that were assessed using 5-level scale. The questionnaires were filled out in the first half of 2015 at different locations in Slovenia where sound baths were performed. The questionnaire 
includes categories and statements in accordance with the findings from accessible surveys in scientific writings and experiences of professionally skilled therapists. To provide reliability, the questionnaire was sent only to the users who have attended sound baths in time span of at least one year. To assure the objectivity of the instrument, the survey was conducted by sending the questionnaire to the users via email.

The data analysis was performed using SPSS programme, with methods of descriptive and inference statistics which include frequency distribution, descriptive statistics and Kruskall-Wallis nonparametric test.

\section{Results and interpretations}

Time span of experiences in sound therapies with gongs

In this chapter, time span of the users' experiences of sound therapy with gongs is presented.

\begin{tabular}{|l|c|c|}
\hline $\begin{array}{l}\text { For how long have you known gongs } \\
\text { and sound baths? }\end{array}$ & F & f \% \\
\hline less than a year & 22 & 17.1 \\
\hline one to two years & 22 & 17.1 \\
\hline more than two years & 85 & 65.9 \\
\hline Total & 129 & 100.0 \\
\hline
\end{tabular}

Table 4: Time span of experiences in sound therapy with gongs.

According to the results in the table almost two thirds (65,9\%) of the users have known sound baths with gongs for more than two years. However, the shares of those who have known the sound therapies less than a year and those who have known them up to two years are equal (17.1\%). We can conclude that the majority of respondents have rich experiences, which adds some extra weight to the results.

\begin{tabular}{|l|c|c|c|c|c|}
\cline { 2 - 5 } \multicolumn{1}{c|}{} & $\mathrm{n}$ & Min & Max & & $\mathrm{s}$ \\
\hline $\begin{array}{l}\text { For how long have you known } \\
\text { gongs and sound baths? }\end{array}$ & 84 & 3 & 15 & 5.82 & 2.53 \\
\hline
\end{tabular}

Table 5: Time span of sound therapies at individuals with more two-year experiences.

A more detailed analysis of experiences at only those users who have known gongs more than two years shows that these users have had a bit less than 6 years of experiences on average (=5.62). Some of them have known sound therapies for as manny as fifteen years. In Slovenia, the education under the supervision of Don Conreaux has started more than ten years ago. Since then, more than a hundred learners completed 
the training and now perform sound baths more or less frequently. Those who have known these musical instruments for about fifteen years have got acquainted with gongs and their relaxing effects outside Slovenia.

\section{Feelings at sound baths with gongs}

In this part of the questionnaire, the users expressed their straightforward feelings during sound baths with gongs. On the list of description of feelings, they could mark those feelings they meant had been sensed. The description of feelings in the table is ranged from the one chosen by most users to the one chosen by fewest users. The respondents could mark more than one answer.

\begin{tabular}{|l|c|}
\hline Feelings at gong sounds & $\mathrm{f} \%$ \\
\hline I can completely indulge in the sound and enjoy. & $27.4 \%$ \\
\hline I can feel the sound as an extremely strong vibration. & $23.0 \%$ \\
\hline "I move" into another time and surroundings. & $15.1 \%$ \\
\hline I can feel slight pain in the blocked parts of my body. & $12.3 \%$ \\
\hline My mind is brimming with thoughts. & $9.0 \%$ \\
\hline Memories form the past wake up. & $5.2 \%$ \\
\hline I feel fear at stronger sounds. & $4.1 \%$ \\
\hline I might go through unpleasant experiences. & $3.8 \%$ \\
\hline
\end{tabular}

Table 6: Feelings during sound therapies with gongs.

The majority ( $27.4 \%$ ) of users of the sound bath with gong can completely indulge in the sound and good feelings during the session. About $23 \%$ of individuals feel the sound as an extremely strong vibration, $15.1 \%$ of them move into another time and surroundings. Some over a one tenth (12.3\%) of the users can feel slight pains in the parts of the body with blockades in the form of fractures from the past, surgeries and other physical problems. As testified, these pains fade away and do not come back in the following sound sessions. About $9 \%$ of individuals feel confusing thinking process which originates in momentary disagreements and overload or some unsolved events from the past. Some individuals report on memories of past events or feel fear at stronger sounds, $3.8 \%$ can go through some other unpleasant experiences, too. Since the answers reflect years of attending sound baths, we can conclude that they present positive experience for all the participants otherwise they would not have repeated them. Experiencing negative expressions reflects recognition of negative subconscious patterns which can be outdone with sound and other ways of relaxation and healing. Continuous use of sound baths definitely results from positive reflexions experienced by individuals at relaying by means of sound. 
The users were offered a list of physical and mental states with the statement that sound bath effects each of these stats positively. The users have expressed their agreement with favourable effect of sound baths on particular psychophysical state with five-grade scale. The degrees of agreement spanned from 1 (The statement is not true) to 5 (The statement is completely true). Individual statements were then joined into some categories: inner peace, better psychophysical condition, impetus for work and desire for personal growth.

\begin{tabular}{|c|c|c|c|}
\hline \multirow{2}{*}{ Psychopbysical states } & \multirow{2}{*}{$\overline{\mathrm{R}}$} & \multicolumn{2}{|c|}{ Kruskall-Wallis } \\
\hline & & $\chi^{2}$ & $\mathrm{P}$ \\
\hline better psychophysical condition & 3.96 & \multirow{4}{*}{287.335} & \multirow{4}{*}{0.000} \\
\hline impetus for work & 2.86 & & \\
\hline inner peace & 1.70 & & \\
\hline desire for personal growth & 1.47 & & \\
\hline
\end{tabular}

Table 7: Psychophysical states favourably influenced by sound baths.

As the most beneficent effect of sound therapy the users stated the improvement of psychophysical condition and fresh impetus for work. A bit weaker beneficent effect was attributed to gaining inner peace, however the smallest effect is attributed to the desire for personal growth.

Each of the categories mentioned was further checked according to the difference in the degree of agreement with statements on the effect of sound baths regarding age, education background, frequency of using sound baths and the time span of experience with the gong therapies and sound baths.

\begin{tabular}{|c|c|c|c|}
\hline \multirow{2}{*}{ Inner peace/Age } & \multirow{2}{*}{$\overline{\mathrm{R}}$} & \multicolumn{2}{|c|}{ Kruskall-Wallis } \\
\hline & & $\chi^{2}$ & $\mathrm{P}$ \\
\hline under 30 years & 35.56 & \multirow{4}{*}{18.839} & \multirow{4}{*}{0.000} \\
\hline $30-40$ years & 60.69 & & \\
\hline $40-50$ years & 76.58 & & \\
\hline over 50 years & 60.40 & & \\
\hline Inner peace /Education & $\overline{\mathrm{R}}$ & $\chi^{2}$ & $\mathrm{P}$ \\
\hline secondary school & 64.48 & \multirow{3}{*}{0.102} & \multirow{3}{*}{0.950} \\
\hline higher education or university & 62.33 & & \\
\hline master's degree/Phd & 63.42 & & \\
\hline
\end{tabular}


MUZIKOLOŠKI ZBORNIK • MUSICOLOGICAL ANNUAL LII/2

\begin{tabular}{|c|c|c|c|}
\hline Inner peace /Frequency & $\overline{\mathrm{R}}$ & $\chi^{2}$ & $\mathrm{P}$ \\
\hline once a week & 72.58 & \multirow{4}{*}{5.966} & \multirow{4}{*}{0.113} \\
\hline twice a month & 61.50 & & \\
\hline once a month & 77.71 & & \\
\hline $\begin{array}{l}\text { occasionally, less than once a } \\
\text { month }\end{array}$ & 59.09 & & \\
\hline Inner peace/Experiences & $\overline{\mathrm{R}}$ & $\chi^{2}$ & $\mathrm{P}$ \\
\hline less than a year & 49.43 & \multirow{3}{*}{4.263} & \multirow{3}{*}{0.119} \\
\hline one to two years & 65.60 & & \\
\hline more than two years & 65.78 & & \\
\hline
\end{tabular}

Table 8: Agreement with statements on beneficent effect of sound baths regarding inner peace according to factors.

The agreement with statements on beneficent effect of sound baths regarding inner peace is most evident at users aged between 40 and 50, which are followed by users aged between 30 and 40 and those over 50 years. The agreement with beneficent effect of sound baths with gongs regarding inner peace is the lowest at users younger than 30 years. The difference among age groups is statistically significant $\left(\chi^{2}=18.839, \mathrm{P}\right.$ $=0.000)$. According the results we can conclude, that individuals aged between 30 and 50 suffer the strongest psychophysical stress and sound baths with gongs efficiently contributes to establishing their inner balance.

The degree of agreement with statements on beneficent effect of sound baths regarding inner peace among users of different formal education backgrounds is not statistically significant $\left(\chi^{2}=0.102, \mathrm{P}=0,150\right)$.

The degree of agreement with statements on beneficent effect of sound baths regarding inner peace among users who use baths variously often is not statistically significant $\left(\chi^{2}=5.966, \mathrm{P}=0.113\right)$. Those users who use baths once a week or once a month testify on higher degree of agreement with statements on beneficent effect of sound baths than their occasional users.

We found out that positive effect of sound baths on establishing inner peace is recognised only after a longer period of their use. The results show that the degree of agreement on beneficent effect of sound baths with gongs regarding inner peace rises after a year of using sound baths. At those with less than a year-long experiences beneficent effect is not recognised to that extent. Nevertheless, we can conclude that the differences among users with different time span of experiences are not statistically significant at assessing the effect of sound baths on establishing inner peace $\left(\chi^{2}\right.$ $=4.263 \mathrm{P}=0.119$ ). 
A. PESEK, T. BRATINA • GONG AND ITS THERAPEUTIC MEANING

\begin{tabular}{|c|c|c|c|}
\hline \multirow{2}{*}{ Better psychophysical condition/Age } & \multirow{2}{*}{$\overline{\mathrm{R}}$} & \multicolumn{2}{|c|}{ Kruskall-Wallis } \\
\hline & & $\chi^{2}$ & $\mathrm{P}$ \\
\hline under 30 years & 46.41 & \multirow{4}{*}{5.622} & \multirow{4}{*}{0.132} \\
\hline $30-40$ years & 62.70 & & \\
\hline $40-50$ years & 69.28 & & \\
\hline over 50 years & 71.18 & & \\
\hline Better psychophysical condition/Education & $\overline{\mathrm{R}}$ & $\chi^{2}$ & $\mathrm{P}$ \\
\hline secondary school & 71.00 & \multirow{3}{*}{1.636} & \multirow{3}{*}{0.441} \\
\hline higher education or university & 61.87 & & \\
\hline master's degree/Phd & 69.08 & & \\
\hline Better psychophysical condition/Frequency & $\overline{\mathrm{R}}$ & $\chi^{2}$ & $\mathrm{P}$ \\
\hline once a week & 87.92 & \multirow{4}{*}{14.707} & \multirow{4}{*}{0.002} \\
\hline twice a month & 96.57 & & \\
\hline once a month & 80.60 & & \\
\hline occasionally, less than once a month & 57.78 & & \\
\hline Better psychophysical condition/Experiences & $\overline{\mathrm{R}}$ & $\chi^{2}$ & $\mathrm{P}$ \\
\hline less than a year & 55.39 & \multirow{3}{*}{1.813} & \multirow{3}{*}{0.404} \\
\hline one to two years & 65.82 & & \\
\hline more than two years & 67.28 & & \\
\hline
\end{tabular}

Table 9: Agreement with statements on beneficent effect of sound baths regarding psychophysical condition according to factors.

The difference in agreement with statements on beneficent effect of sound baths regarding better psychophysical condition is not statistically significant $\left(\chi^{2}=5.622 \mathrm{P}=\right.$ 0.132 ) among the users of different ages. The results testify that beneficent effects of sound baths on better physic and mental condition are more recognised among users aged over 30 years.

The same opinion on beneficent effect of sound baths regarding better psychophysical condition is shared by users with secondary education as well as those with higher education or university or academic titles. The difference in agreement with statements is not statistically significant among the groups $\left(\chi^{2}=1.636 \mathrm{P}=0.441\right)$.

The results testify that beneficent effects of sound baths on better psychophysical condition according to users rise with the frequency of use. The differences among users who visit the events variously often are statistically significant $\left(\chi^{2}=14.707 \mathrm{P}=0.002\right)$. The highest degree of agreement with statements on beneficial effect of sound baths on better psychophysical condition is testified by users who use baths twice a month. The lowest degree of agreement is found at occasional users. Similar distribution can be noted at the result of analysis on differences among users with different time span of experiences where the degree of agreement with statements on beneficent effect of 
sound baths on better psychophysical condition rises according to time span of experiences with sound baths with gongs. Nevertheless, the differences among users with different time span of experiences are not statistically significant $\left(\chi^{2}=1.813 \mathrm{P}=0.404\right)$.

\begin{tabular}{|c|c|c|c|}
\hline \multirow{2}{*}{ Impetus for work/Age } & \multirow{2}{*}{$\overline{\mathrm{R}}$} & \multicolumn{2}{|c|}{ Kruskall-Wallis } \\
\hline & & $\chi^{2}$ & $\mathrm{P}$ \\
\hline under 30 years & 53.93 & \multirow{4}{*}{2.561} & \multirow{4}{*}{0.464} \\
\hline $30-40$ years & 58.36 & & \\
\hline $40-50$ years & 67.51 & & \\
\hline over 50 years & 66.25 & & \\
\hline Impetus for work/Education & $\overline{\mathrm{R}}$ & $\chi^{2}$ & $\mathrm{P}$ \\
\hline secondary school & 60.58 & \multirow{3}{*}{0.212} & \multirow{3}{*}{0.899} \\
\hline higher education or university & 63.87 & & \\
\hline master's degree/Phd & 63.85 & & \\
\hline Impetus for work/Frequency & $\overline{\mathrm{R}}$ & $\chi^{2}$ & $\mathrm{P}$ \\
\hline once a week & 81.33 & \multirow{4}{*}{11.468} & \multirow{4}{*}{0.009} \\
\hline twice a month & 84.86 & & \\
\hline once a month & 78.52 & & \\
\hline occasionally, less than once a month & 56.53 & & \\
\hline Impetus for work/Experiences & $\overline{\mathrm{R}}$ & $\chi^{2}$ & $\mathrm{P}$ \\
\hline less than a year & 57,40 & \multirow{3}{*}{0.619} & \multirow{3}{*}{0.734} \\
\hline one to two years & 64.98 & & \\
\hline more than two years & 63.84 & & \\
\hline
\end{tabular}

Table 10: Agreement with statements on beneficent effect of sound baths regarding impetus for work according to factors.

The differences in degrees of agreement with statements on beneficent effect of sound baths regarding impetus for work are not statistically significant among the users of different ages $\left(\chi^{2}=2.561 \mathrm{P}=0.464\right)$. However, the results testify that beneficent effect of sound baths at impetus for work is to a larger extent sensed at users aged between 40 and 50 and older users.

Regardless of education background, the agreement with statements on beneficent effect of sound baths regarding impetus for work is quite similar, so the difference in the degree of agreement on statements among users with different levels of education is not statistically significant $\left(\chi^{2}=0.212 \mathrm{P}=0.899\right)$.

The differences in degrees of agreement with statements on beneficent effect of sound baths regarding impetus for work are statistically significant among the users who use baths variously often $\left(\chi^{2}=11.468 \mathrm{P}=0.009\right)$. Such a result testifies that sound baths have the most beneficent effect when they are used more often. The highest 
degree of agreement with statements is noted with users who use sound baths once a week or once to twice a month. Regardless the time span of experiences, the beneficent effect of sound baths on impetus for work is equally perceived with all users. The difference in the degree of agreement on statements among users with time span of experiences is not statistically significant $\left(\chi^{2}=0.619 \mathrm{P}=0.734\right)$.

\begin{tabular}{|c|c|c|c|}
\hline \multirow{2}{*}{ Desire for personal growth/Age } & \multirow{2}{*}{$\overline{\mathrm{R}}$} & \multicolumn{2}{|c|}{ Kruskall-Wallis } \\
\hline & & $\chi^{2}$ & $\mathrm{P}$ \\
\hline under 30 years & 63.81 & \multirow{4}{*}{1.173} & \multirow{4}{*}{0760} \\
\hline $30-40$ years & 55.75 & & \\
\hline $40-50$ years & 61.07 & & \\
\hline over 50 years & 55.19 & & \\
\hline Desire for personal growth/Education & $\overline{\mathrm{R}}$ & $\chi^{2}$ & $\mathrm{P}$ \\
\hline secondary school & 64.33 & \multirow{3}{*}{2.529} & \multirow{3}{*}{0.282} \\
\hline higher education/university & 57.74 & & \\
\hline master's degree/Phd & 47.54 & & \\
\hline Desire for personal growth/Frequency & $\overline{\mathrm{R}}$ & $\chi^{2}$ & $\mathrm{P}$ \\
\hline once a month & 90.00 & \multirow{4}{*}{10.258} & \multirow{4}{*}{0.016} \\
\hline twice a month & 72.43 & & \\
\hline once a month & 67.55 & & \\
\hline occasionally, less than once a month & 53.14 & & \\
\hline Desire for personal growth/Experience & $\overline{\mathrm{R}}$ & $\chi^{2}$ & $\mathrm{P}$ \\
\hline less than a year & 65.03 & \multirow{3}{*}{1.267} & \multirow{3}{*}{0.531} \\
\hline one to two years & 61.03 & & \\
\hline more than two years & 56.35 & & \\
\hline
\end{tabular}

Table 11: Agreement with statements on beneficent effect of sound baths regarding desire for personal growth according to factors.

The agreement with statements on beneficent effect of sound baths regarding the desire for personal growth slightly differs among the users of different ages. The differences among rates of agreement are not statistically significant $\left(\chi^{2}=1.173, \mathrm{P}=0.760\right)$. Based on the results, it can be concluded that perceiving beneficent effect of sound baths on the desire for personal growth does not depend on the age of users.

The difference in the degree of agreement on statements about beneficent effect on the desire for personal growth with different level of education is not statistically significant $\left(\chi^{2}=2.529, \mathrm{P}=0.282\right)$. However, it can be noted from the results that sound baths with gongs encourage the desire for personal growth more with users who have completed secondary education than users with the highest level of education. We can conclude that, due to potential higher income, users with higher level of education 
have better access to corresponding literature and extra education and can, consequently, more successfully fulfil the desire for personal growth.

Based on the results we can conclude that more frequent use of sound baths with gongs encourages the desire for personal growth. Users who use the baths once a week testify the highest degree of agreement with statements on beneficent effect of sound baths on the desire for personal growth. They are followed by users who use the baths twice a month. The lowest degree of agreement can be noted at occasional users. The difference in agreement with statements among users with different frequency of use is statistically significant $\left(\chi^{2}=10.258, \mathrm{P}=0.016\right)$.

Regarding the time span of experiences of sound therapies with gongs, the results testify that the agreement with statements on beneficent effect of sound baths on the desire for personal growth diminishes slightly when the users get to know the sound baths better. Users with the longest time span of experiences with sound baths agree with the statements on the effect on the desire for personal growth to a slightly smaller extent. We can assume that after a longer span of use of sound baths, users reach and perceive a certain level of the desired personal maturity and do not strive for new experiences again and again. The difference among levels of agreement regarding the time span of experience at sound baths with gongs is not statistically significant $\left(\chi^{2}=\right.$ $1.267, \mathrm{P}=0.531$ ).

\section{Intensity of sound baths}

We were interested in most desired intensities of sound baths. The users could choose among baths of moderate volume, acoustically diverse and very loud baths.

\begin{tabular}{|l|c|c|}
\hline Intensity of sound baths & $\mathrm{f}$ & $\mathrm{f} \%$ \\
\hline moderate volume & 62 & 48.1 \\
\hline acoustically diverse & 55 & 42.6 \\
\hline very loud & 12 & 9.3 \\
\hline Total & 129 & 100.0 \\
\hline
\end{tabular}

Table 12: Desired intensity of sound baths.

Almost a half ( $48.1 \%$ ) of respondents express the wish for baths of moderate volume and a similar share expresses the wish for acoustically diverse baths. The fewest (9.3\%) are the users desiring very loud sound baths. Regarding the feelings expressed after sound baths (Table 12) the result is predictable. It needs to be mentioned that very loud sound baths can provoke unforeseen physical and mental reactions since strong vibrations may evoke potential fears and traumas stored in the subconscious. In psychiatry, therapists use them for diagnostics and treatment. However, inexperienced performers of sound baths should not use them since they are not skilled to treat psychiatric conditions. 


\begin{tabular}{|l|l|l|}
\hline What is your definition of a sound bath? & f & f \% \\
\hline healing and relaxation & 100 & 77.5 \\
\hline Healing & 3 & 2.3 \\
\hline relaxation & 26 & 20.2 \\
\hline Total & 129 & 100.0 \\
\hline
\end{tabular}

Table 13: Definition of sound baths.

Most users - more than three quarters (77.5\%) define sound baths as a combination of healing and relaxation which shows the awareness that relaxation is a precondition for any successful treatment. Relaxation effects dominates the definition by 20,2\% of users and healing effect by only $2,3 \%$ users. Some of the later have even attributed permanent healing to the sound.

\section{Conclusion}

The awareness of therapeutic effect of the sound can be found in different historical periods and geographic areas. In the Western world, the use of sound for therapeutic purposes has mostly been reduced and supplanted by allopatic medicine, which uses sound basically for diagnostic purposes (ultrasound) and some kinds of therapy (infrasound, mostly for physiotherapy).

Many studies have shown positive results in the field of healing with sound. Peter Hess' systematic study was the first in the West to present the results of scientific research on therapeutic work with Himalayan singing bowls. In 2002, a pilot study ${ }^{63}$ was published which explained the effect of sound on 266 therapists who provide relaxation and healing with sound. The results testified that the Peter Hess' therapeutic method was not only useful for relaxation but also in overcoming stress resulting for example in headaches, pains in the back and shoulders, sleeplessness and inner restlessness. Playing the Himalayan singing bowls, gongs and other musical instruments which can be done individually or together proved successful for work with persons with special needs ${ }^{64}$, after rehabilitations following a stroke, car accidents and other calamities. ${ }^{65}$ The studies also testify on positive effects at neurological disorders, at regulating variability of heart pace, cognitive processes of memorising and encouraging creativity. ${ }^{66}$

63 Christina Koller, Peter Hess, Klangmassage nach Peter Hess ${ }^{\circledR}$ in der Praxis. Erhebung zur Anwendung in der Praxis durchgeführt am Institut für Klang-Massage-Therapie (Uenzen: Verlag Peter Hess, 2005).

64 This note names a journal dedicated entirely to therapeutic work with special needs persons: Peter Hess, "Klangmethoden und Menschen mit Behinderungen," Klang-Massage-Therapie (Uenzen: Peter Hess, 8/2011).

65 Herald Titzer, "Klangmassage auf der Intensivstation. Entwicklung und Forschung rund die Peter Hess-Klangmethoden," Klang-Massage-Therapie 9 (2014): 34-37.

66 Alexandra Pronegg, "Die Auswirkungen der Peter Hess-Klangmassage auf das Konzentrationsverhalten von Kindern im Grundschulalter," Klang-Massage-Therapie 9 (2014): 53-57.

Andrea Laake, Mark Fürst, "Klangcoaching an Berufsbildenden Schulen. Ein Weg zu mehr Lernmotivation, emotionaler Zufriedenheit sowie Selbstwirksamkeit durch Stärkung des subjektiven Selbstkonzepts," Klang-Massage-Therapie 9 (2014): 58-62. 
The survey on the impact of sound baths on users carried out in Slovenia in 2015 testifies on positive effects on psychophysical well-being of individuals. Each and every respondent agreed that sound baths present relaxation and/or healing for him or her and all of them would recommend these sound events to others. Three respondents added even that the sound bath has brought them to a complete recovery.

It would be worth to consider use of sound baths, guided by educated sound theraphists within the programmes of relaxation in schools, hospitals, factories and other working environments. Our current existence is often overwhelmed by stress that results in long-term psychophysical imbalances. We could at least partially alleviate it by popularising sound events that would offer relaxation and easier coping with work tasks and interpersonal relations.

\section{Bibliography}

Abel, Sharon M. "The Extra-auditory Effects of Noise and Annoyance: An Overview of Research". Journal of Otolaryngology 1 (1990): 1-13.

American Music Therapy Association. Accessed on August 6, 2016, http://www.musictherapy.org/about/quotes/.

Andrews, Ted. Sacred Sounds: Magic \& Healing Through Words \& Music. St. Paul: Llewellyn Publications, 1992.

Barcal, Jan, Vozeh, Frantisek. "Effect of Whole-Body Exposure to HighFrequency Electromagnetic Field on the Brain Cortical and Hippocampal Activity in Mouse Experimental Model". NeuroQuantology 5/3 (2007): 292-302.

Benton, Mehtab. Gong joga. Zdravljenje in razsvetljevanje s pomočjo zvoka. Ljubljana: Center Sospita Rea Silvia Novak \& Co., 2010.

Berklee College of Music. Accessed on August 6, 2016, from https://www.berklee.edu/ music-therapy.

Blades, James. Percussion Instruments and Their History. Westport: The Bold Strummer, 1992.

Blank, Martin and Reba M. Goodman. "Electromagnetic Fields Stress Living Cells". Pathophysiology 16/2-3 (2009): 71-78.

Brandt, Karin. "Klangmassage-Therapie mit alters-und demenzkranken Menschen". Klang-Massage-Therapy 8 (2011): 10-11.

Bringas, Maria L. et al. Frontiers in Neuroscience. Accessed on August 6, 2016, http:// journal.frontiersin.org/article/10.3389/fnins.2015.00427/full.

Burns, Christopher. "Realizing Lucier and Stockhausen: Case Studies in the Performance Practice of Electroacoustic Music". Journal of New Music Research 1 (2002): 59-68.

Cady, Roger K. and Norman Shealy, Neurochemical Responses to Cranial Electrical Stimulation and Photo-Stimulation via Brain Wave Synchronization. Springfield: Shealy Institute of Comprehensive Health Care, 1990.

Conreaux, Don. Magnum Opus of the Gong. New York: Mysterious Tremendum, 1994.

De Muynck, Marjorie. Sound Healing. Vibrational Healing with Ohm Tuning Forks. Santa Fe: Sound Universe, 2008. 
Deivanayagi, S. et al. "Spectral Analysis of EEG Signals During Hypnosis". International Journal of Systemics, Cybernetics and Informatics 4 (2007): 75-80.

Dictionary.com's 21st Century Lexicon. Accessed on August 7, 2016, http:/www.dictionary.com/browse/electropollution.

Dingle, Genevieve, et al. "Can Music Therapy Engage Patients in Group Cognitive Behaviour Therapy for Substance Abuse Treatment?" Drug and Alcohol Review 27 (2008): 190-196.

Encyclopedia of Alternative Medicine. Accessed on August 6, 2016, http://www.altmd. com/Articles/Sound-Therapy--Encyclopedia-of-Alternative-Medicin.

Fahmy, Heba M. et al. „Effect of Radiofrequency Waves Emitted From Conventional WIFI Devices on Some Oxidative Stress Parameters in Rat Kidney". Drug Metabolism E Toxicology, 6/5 (2015): 1-6.

Fragstein von, Sybille. "Klangmassage-Therapie in der ambulanten Arbeit mit behinderten Menschen. Klangmassage-Therapie mit alters- und demenzkranken Menschen”. Klang-Massage-Therapy 8 (2011): 12-14.

Frohne, Isabelle. "Gongspiel und Gegenwart”. Heilende Klänge. Der Gong in Therapie, Meditation und Sound Healing. Uenzen: Verlag Peter Hess, 2007, 9-22.

Gibson, David. The Complete Guide to Sound Healing. San Francisco: Sound Healing Center.

Hameroff, Stuart et al. "Transcranial Ultrasound (TUS) Effects on Mental States: A Pilot Study". Brain Stimulation 6/3 (2013): 409-415.

Hess, Peter. Singing Bowls for Health and Inner Harmony. Uenzen: Verlag Peter Hess, 2008.

Hess, Peter. "Klangmethoden und Menschen mit Behinderungen”. Klang-MassageTherapie. Uenzen: Verlag Peter Hess, 8/2011.

"How Science Discovered The Silva Method". Accessed on August 2, 2016, http://www. silva.nl/wp-content/uploads/2014/12/science-discovers-the-silva-method.pdf.

Huang, Tina L. and Christine Charyton, "Comprehensive Review of the Psychological Effects of Brainwave Entrainment". Alternative Therapies 14/5 (2008): 38-49.

Hüne, Andreas. "Klangmassage bei Menschen mit psyhischer Behinderung”. KlangMassage-Therapy 8 (2011): 40-41.

International Gong Master Website. Accessed on August 11, 2016, http://www.toneoflife.com.pl/don/gong-master-training-online/gong-master-training-certification.

"Heinrich Wilhelm Dove". Proceedings of the American Academy of Arts and Sciences, 15: 383-391. Accessed on August 5, 2016, https://www.jstor.org/ stable/25138588?seq=9\#page_scan_tab_contents.

Jinah, Kim. "Emotional, Motivational and Interpersonal Responsiveness of Children with Autism in Improvisational Music Therapy". Autism 13/4 (2009): 389-409.

Kalinga Dona, Lasanthi Manaranjanie. Music and Healing Rituals of Sri Lanka. Their Relevance for Community Music Therapy and Medical Ethnomusicology. Colombo: S. Godage \& Brothers, 2013.

Koller, Christina and Peter Hess, Klangmassage nach Peter Hess ${ }^{\circledR}$ in der Praxis. Erhebung zur Anwendung in der Praxis durchgeführt am Institut für Klang-MassageTherapie. Uenzen: Verlag Peter Hess, 2005. 
Laake, Andrea and Mark Fürst, "Klangcoaching an Berufsbildenden Schulen. Ein Weg zu mehr Lernmotivation, emotionaler Zufriedenheit sowie Selbstwirksamkeit durch Stärkung des subjektiven Selbstkonzepts". Klang-Massage-Therapie 9 (2014): 58-62.

Lázaro, Amparo et al. "Electromagnetic Radiation of Mobile Telecommunication Antennas Affects the Abundance and Composition of Wild Pollinators". Journal of Insect Conservation 20/2 (2016): 315-324.

Le Scournec, René-Pierre et al. "Use of Binaural Beat Tapes for Treatment of Anxiety: A Pilot Study of Tape Preference and Outcomes". Alternative Therapies in Health and Medicine 7/1 (2001): 58-63.

Malek, Mojca. "Pogovor s starešino mojstrov kundalini krija in gong joge Donom Conreauxom: Zvok gonga ruši zidove med ljudmi”. Sončeve pozitivke, 2006. Accessed on February 4, 2015, http://www.pozitivke.net/article. php?story=Zvok_Planetarni_Gongi_Don_Conreaux\&query=gongov.

Malek, Mojca. Zvočna masaža. Accessed on June 15, 2016,

McNamara, Philip. Gongs and Tam-Tams: A Guide for Percussionists, Drummers and Sound Healers. Layerthorpe: York Publishing Services, 2012.

Meriam-Webster Dictionary. Accessed on August 7, 2016, http://www.merriam-webster. com/dictionary/meridian.

Moore, Kimberly Sena. "A Systematic Review on the Neural Effects of Music on Emotion Regulation: Implications for Music Therapy Practice". Journal of Music Therapy 3 (2013): 198-242.

Morris, Suzzane. The Facilitation of Learning. Self-publishing, 1973.

Oster, Gerald. "Auditory Beats in the Brain". Scientific American (1973): 94-102.

Ostrander, Sheila et al. Super-Learning 2000. New York: Dell Publishing, 1997.

Pearce, Stewart. Alkimija glasu. Brežice: Založba Primus, 2011.

Perry, Wayne. Sound Medicine. The Complete Guide to Healing with Sound and the Human Voice. Los Angeles: Musikarma Publishing, 2007.

Povey, Glenn. Echoes: The Complete History of Pink Floyd. Bovingdon: Mind Head Publishing, 2007.

Pronegg, Alexandra. "Die Auswirkungen der Peter Hess-Klangmassage auf das Konzentrationsverhalten von Kindern im Grundschulalter". Klang-Massage-Therapie 9 (2014): 53-57.

Rose, Colin and Malcolm J. Nicholl,. Accelerated Learning for the 21st Century. New York: Dell Publishing, 1998.

Sage Academy of Sound Energy. Accessed on August 5, 2016, http://www.sageacademyofsoundenergy.com/gong-camp-wdon-conreaux-at-ananda-ashram-new-york. html.

Scott, Gini Graham. Shamanism. New York: Alpha, 2002.

Silber, Otto-Heinrich, et al. Klangtherapie. Battweiler: Traumzeit-Verlag, 2007.

Sound \& Consciousness Globe Institute, 2013. Accessed on July 16, 2016, http://www. soundhealingcenter.com/instructors.html

Sveinsdóttir, Herdís and Jón Snædal. "Music Therapy in Moderate and Severe Dementia of Alzheimer's Type: A Case-control Study". International Psychogeriatrics 18/4 (2006): 613-621. 
Szabó, Csaba. "The Effects of Monotonous Drumming on Subjective Experiences”. Music Therapy Today 1 (2004): 1-9.

Talwar, Nakul et al. "Music Therapy For In-patients With Schizophrenia". The British Journal of Psychiatry 189/5 (2006): 405-409.

Titzer, Herald. "Klangmassage auf der Intensivstation. Entwicklung und Forschung rund die Peter Hess-Klangmethoden”. Klang-Massage-Therapie 9 (2014): 34-37.

Tomatis, Alfred A. The Conscious Ear. Barrytown: Station Hill Press, 1991.

Wahbeh, Helane et al. "Binaural Beat Technology in Humans: A Pilot Study to Assess Psychological and Physiologic Effects". Journal of Alternative and Complementary Medicine 13/1 (2007): 25-32.

Watkins, Gwendolin R. "Proposed Physiological Mechanisms and Clinical Implications: Clinical Nurse Specialist". The International Journey for Advanced Nursing Practice 11 (1997): 43-50.

Whittaker, Sheila. Sound Healing With Gongs. York: Healing Sound, 2010.

Wigram, Tony, et al. A Comprehensive Guide to Music Therapy: Theory, Clinical Practice, Research and Training. London: Jessica Kingsley Publishers, 2002.

POVZETEK

Zvočna terapija je zavestna terapevtska aplikacija zvočnih frekvenc za namene izboljšanja zdravja; posamezniku naj bi pomagala, da se vrne v stanje harmonije telesa in duha. Zvočna terapija izhaja iz domneve, da je človeško telo sestavljeno iz niza vibracij, ki se v času bolezni pomešajo in izpadejo iz ritma. Da bi bolje razumeli zvočno terapijo, se moramo zavedati, da v vesolju vse vibrira: atomi, celice in živa materija. Izbrani zvočni valovi vstopijo v telo in ponovno vzpostavijo ravnovesje valovanja tam, kjer se je le-to zaradi vplivov bolezni spremenilo. Zelo učinkovita metoda uporabe zvoka v terapevtske namene so zvočne kopeli z gongi in drugimi glasbili s širokim spektrom alikvotnih tonov, ki ponovno vzpostavijo psihoelektromagnetsko polje na osnovi specifičnih ozkih frekvenčnih razmerij. Obstajajo mnoge razlage, kako je gong nastal, večina teorij pa se sklicuje na rojstvo tega inštrumenta v bronasti dobi. Skozi stoletja se je gong pojavljal tako v vzhodnih kot zahodnih glasbah in bil sestavni del različnih dogodkov. Iniciativo za terapevtsko rabo inštrumenta je v sedemdesetih letih 20. stoletja podal Don Conreaux. Praksa in raziskave so potrdile pozitivne učinke zvočnih vibracij gonga pri vzpostavljanju psihofizičnega ravnovesja, kar je predpogoj za zdravljenje in odpravljanje vzrokov bolezni.

$\mathrm{V}$ namene preučevanja vpliva zvoka je bila leta 2015 v Sloveniji izvedena raziskava s 129-imi udeleženci različnih starostnih skupin in izobrazbenih ozadij, ki so se udeležili zvočnih kopeli z gongi in drugimi inštrumenti. Rezultati so pokazali, da je izpostavljenost terapevtskim zvokom učinkovala na posameznike zdravilno in/ali sprostitveno, jim večinoma pomagala do notranjega miru, novega zagona za delo, dvignila željo za osebno rast in nasploh prispevala k boljšemu počutju. Vsi anketiranci bi izkušnjo priporočili drugim. Izsledki raziskave potrjujejo, da so zvočne kopeli učinkovito sredstvo za premagovanje stresa in da bi kot vrsta sprostitve in terapevtske pomoči lahko postale del rednih praks za preprečevanje negativnih psihofizičnih stanj in del asistence pri zdravljenju. 